\title{
Economics: What to Do About an Unreformable Discipline?
}

\author{
Steve Keen \\ Honorary Professor, University College London and \\ Distinguished Research Fellow, Institute for Strategy, Resilience \& Security, London
}

\begin{abstract}
The 2008 crisis was an obvious anomaly for mainstream Neoclassical economic theory, and yet a decade after the crisis, the Neoclassical school still dominates the discipline and is largely unchanged. I argue that the separation of academic economics from the consequences of its empirical failures means that it is extremely unlikely that academic economics will be reformed. Instead, if change is to occur within economics, it will likely be led by institutions like central banks and treasuries which are under at least some pressure to produce useful economic forecasts. Apart from this, I hold out hope that emerging disciplines such as complex system analysis will supplant economics itself. I also encourage all would-be students of economics to join the Rethinking Economics network and teach themselves non-mainstream economics using the resources of the internet.
\end{abstract}

Keywords: Pedagogy, Paradigms, Education, Macroeconomics, Complex systems.

JEL Classification: A2, B59, P41, Y8

KAUJIE Classification: G0, G6, G63 


\section{How Relevant is the Economics Profession to Pressing Real World Problems?}

At present, the dominant approach within economics (Neoclassical economics), is actually antipathetic to the real-world problems (e.g., poverty, inequality, unemployment, global warming, financial crises, etc.) that communities are facing all over the globe.

As Reardon (2019, p. 68) points out in his lead paper, the Neoclassical school explicitly rejected the class-based analysis of the preceding Classical school. In place of differentiated social classes, whose income sources and relative incomes differed substantially - workers earning wages, capitalists earning profits, landlords earning rents and bankers earning interest - they hypothesized "atomistic" consumers maximizing utility subject to an undifferentiated "budget constraint", facing profit maximizing firms restrained by both competitive forces and diminishing marginal productivity, and tried to derive all of economics from that perspective.

They failed, as they themselves proved in what is known as the Sonnenschein-Mantel-Debreu theorem (Sonnenschein, 1972): while a "downward sloping demand curve" can be derived from Neoclassical theory for an individual consumer, that result does not hold for a market demand curve when changing relative prices alter the distribution of income. This implies that the distribution of income is an essential factor in economics, but since income distribution is abstracted from in the foundations of Neoclassical theory, they are in no position to comment upon it.

They also ignored, as did the Classicals themselves, the focus upon the role of land in economics that was a hallmark of the preceding Physiocratic school (Cantillon, 1755/2010; Quesnay, 1759). They modelled output as the result of the combination of labor and capital alone; no role was ascribed to land at all. This is a flaw that Post-Keynesians also share: they also model production as requiring labor and capital only. However, in the real world, the laws of thermodynamics tell us that nothing can be produced without energy, that energy cannot be created (or destroyed), and that the use of energy to perform work necessarily creates more disorder than order. These thermodynamic insights are absent from all existing economic models, so economics cannot tell us anything fundamentally insightful about the impact of the economy on the ecology. I am working with others to overcome this deficiency (Garrett, 2014; Garrett, 2015; Keen, Ayres, \& Standish, 2019), but for now, the economics profession in general provides no useful guidance on global warming.

The Neoclassical school is also useless on the topic of financial crises, since their macroeconomic models exclude the financial sector, and even money itself. Their dominant macroeconomic modelling tool, the Dynamic Stochastic General Equilibrium (DSGE) model, also imposes what they call a "transversality condition" which is functionally equivalent to assuming that Ponzi finance does not exist. But Ponzi finance is an essential element of real-world financial crises.

The Post-Keynesian school, and specifically the work of Hyman Minsky (Minsky, 1982) and followers of his work like myself (Keen, 1995; Keen, 2015) and others (Grasselli \& Costa Lima, 2012), does provide guidance on financial crises, but we are nonmainstream researchers and our policy recommendations are not known to actual policy makers. Hence, financial crises are likely to continue occurring, and their aftermaths will be poorly addressed.

The world is very poorly served by economics, and this shows little sign of improving in the near future.

\section{Is There A Need for Reform in Mainstream Economics?}

I think there is a stronger case, not for the reform of mainstream economics, but for its overthrow. I see it as very similar to Ptolemaic Astronomy. The Ptolemaic elaborate model of the solar system could actually make quite accurate predictions, but it was completely wrong about the structure of the solar system. They did not reform themselves; instead, reform came from the outside, via the empirical work of Tycho Brahe and the theoretical models of Kepler, Galileo and Copernicus, and ultimately Newton.

The Neoclassical model is, like the Ptolemaic model, plausible to its adherents, but completely wrong about the actual economy. Whereas they ignore the monetary and banking system, these are critical to the actual functioning of the economy. Whereas they assume the stability of economic equilibrium, and treat equilibrium as being a general rule, 
economic equilibria are unstable and the general situation is not equilibrium dynamics, but far from equilibrium dynamics. Their assumptions about the behavior of individual agents in the economy are also wrong. Actual consumers cannot maximize their utility (Sippel, 1997), and actual firms operate under conditions of falling rather than rising marginal cost ( Blinder, Canetti, Lebow, \& Rudd, 1998; Lee, 1999).

Their belief that the macro economy can be treated as a simple extrapolation of microeconomic behavior is also wrong, since as Anderson put it in More is Different: "The behavior of large and complex aggregates of elementary particles, it turns out, is not to be understood in terms of a simple extrapolation of the properties of a few particles" (Anderson, 1972, p. 393).

However Neoclassical economists cling to these beliefs, so that any attempt they make to "reform" economics, or economics education, still treats these ideas as both foundational and sacrosanct. The CORE curriculum is an example of this: it still enforces the perspective of utility maximizing consumers, and firms maximizing profits under conditions of rising marginal cost, even though it pretends to be modernizing economics. There has been no departure from fundamental Neoclassical beliefs.

\section{Is Pluralism the Answer?}

The mainstream Neoclassical viewpoint on this can be summed up by what the late American economist Milton Friedman said: "there is no such thing as different schools of thought in economics; there are only good economics and bad economics" (as quoted in Ebeling, 2010, p. 12).

Friedman was the source of so much bad economics that it's rather laughable to take his word on this: there are certainly schools of economic thought, and most of the bad stuff emanates from the school of thought he champions.

However, I do feel that a "good" economics can be developed once we abandon the $19^{\text {th }}$ century crutches on which Neoclassical economics attempts to walk. These crutches are the insistence on equilibrium analysis, when complex systems (like the weather as well as the economy) are never in equilibrium; abstracting from the existence of banks, debt and money to attempt to model capitalism as a barter system; attempting to derive higher level analysis (macroeconomics) by extrapolation from lower level analysis (microeconomics); and $19^{\text {th }}$ century armchair models of human behavior that are empirically false.

With those crutches removed, a new core of economics could commence from an understanding of the thermodynamic underpinnings of the economy (Keen et al., 2019), knowledge of the complex evolutionary systems approach to modelling systems that operate out of equilibrium all the time (Lorenz, 1963), and awareness of the fundamentally monetary nature of capitalism (Graziani, 1989).

Even if such a core is developed, however, there is still a need for a plurality of approaches. This is evident in the hard sciences as well. All physicists share training in the basics of physics, but they then specialize in particular issues within physics. The same could apply to economics. At present its specializations are defined by Neoclassical theory (microeconomics, macroeconomics, international trade, game theory, etc.). But a properly constituted economics needs specializations on such issues as how does innovation occur, how do economies develop, how do financial crises occur, how does the economy interact with the ecology and broader society?

The day in which that can happen is unfortunately far in the future, so in the interim the best approach is to teach the different schools of thought that have those specializations themselves: Austrian economics for the focus on uncertainty, Post Keynesian for monetary macroeconomics, Evolutionary economics for complex dynamics, and so on. Given that topranked economics departments will almost certainly not offer these courses, self-study by students may be the only option.

\section{Has the Economics Profession Transformed A Decade After The Crisis?}

Economics has proven extremely resistant to change, even after such a paradigm-challenging event as the Global Financial Crisis. Economists went from being absolutely triumphalist about their discipline, to defensive. In 2000, the QJE published a paper entitled "Economic Imperialism" which literally claimed that economics was the only true social science, and that economics could and should take over all other social science disciplines (Lazear, 2000). In 2009, in the depths of the crisis, Olivier Blanchard published a 
paper which asserted that "the state of macro is good" (Blanchard, 2009). Blanchard became more critical of his discipline's failings as the crisis and its aftermath wore on, but even so in 2016 he summarized a debate over macroeconomics in which I took part in the following manner:

A number of economists have recently written about the pros and cons of dynamic stochastic general equilibrium models (DSGEs). (Among them, and in addition to my own piece, are Narayana Kocherlakota, Simon Wren-Lewis, Paul Romer, Steve Keen, Anton Korinek, Paul Krugman, Noah Smith, Roger Farmer, and Brad Delong.) Here are my reactions to the debate:

I believe that there is wide agreement on the following three propositions; let us not discuss them further, and move on:

Macroeconomics is about general equilibrium. (Blanchard, 2016, para 1)

I certainly did not agree with that proposition (nor the two after it), and yet Blanchard could sincerely believe he was summarizing the contending views, including mine - even though I explicitly rejected equilibrium analysis in that debate. The problem is that equilibrium for Neoclassical economists is like water for fish: they take it for granted, and they can't imagine existing without it. So, when someone explicitly rejects equilibrium methodology, Neoclassical economists can't even comprehend their argument.

The problem with expecting economics to reform itself from within is the one identified so well by Thomas Kuhn in discussing how scientific revolutions occur: it is almost never the case that existing practitioners make the leap from one way of thinking to another. They will adjust their paradigm - modify what Lakatos called the "protective belt" of assumptions - while hanging on to its hard core.

Instead someone has to break the mold - as Planck did with quantum mechanics - after which a new generation that takes the new framework for granted displaces the old. As Kuhn remarked:

Max Planck, surveying his own career in his Scientific Autobiography, sadly remarked that "a new scientific truth does not triumph by convincing its opponents and making them see the light, but rather because its opponents eventually die, and a new generation grows up that is familiar with it" [quotation in original]. (Kuhn, 1970, p. 150)
That process seems to abort in economics because core beliefs - about, for example, the imperative to derive economics from the actions of individuals rather than social classes (Krugman, 1996) - are not challenged when economic models derived from those core beliefs fail spectacularly, as they did in 2008. Instead, economists add adjustments to their models to cover the anomaly, and continue teaching the same core beliefs as essential to new students, and constructing their models using them as well. The lessons of the divergence of the real world from both their core beliefs and their models are never learnt.

\section{How Useful and Effective Have Been The Initiatives Taken for Reform?}

These initiatives have certainly kept criticism of economics alive after the crisis, which is a very good thing. My favorite such initiative - which is financially supported by the Institute for New Economic Thinking (INET) - is the Rethinking Economics movement, which has branches now in dozens of universities, particularly in Europe. I encourage any economics student reading these pages to join your local group, or start one if none exists.

However, shifting the basis of the education of young economists away from the Neoclassical core has proven impossible at the vast majority of universities. The CORE project has made this intransigence worse, by giving economics departments a way to appear to move to a more enlightened text than, say, Mankiw, without at all challenging the foundational beliefs of Neoclassical economics, as Reardon (2019, pp. 66-67) also points out.

The "top journals" remain impenetrable to any approach which is not rooted in Neoclassical equilibrium thinking.

Overall, I see university economics departments as a lost cause for the reform of economics itself. Neoclassical economists will always dominate the top ranked universities and top ranked journals, and will operate as gatekeepers against pluralism. This is one reason that I am delighted that so many universities have a Rethinking Economics movement, because I think that critical students will at least be able to teach themselves using the resources of the modern information age, while simultaneously making life uncomfortable for their Neoclassical professors. 
For any chance of progress in economics, I turn to non-economics departments at universities, and institutions like Treasuries and Central Banks, which are under at least some pressure to produce models that approximate reality.

Non-economics disciplines that require some economics in their students' training - such as accounting and auditing - are already dissatisfied with the courses economics departments provide. These courses (introductory economics, perhaps an amalgam of microeconomics and macroeconomics, perhaps a first year course in one or the other) teach that "money doesn't matter", effectively disparaging these professions by arguing that what they analyze the monetary system as it is expressed in the balance sheets of the corporations that employ them - is of ephemeral importance. Given the failure of mainstream economics to anticipate the Global Financial Crisis, these professions are even less happy with what their students learn from economics departments, and might well put on their own courses where non-mainstream views on money and banking will receive an airing.

Central Banks - the Bank of England (McLeay, Radia, \& Thomas, 2014) and the Bundesbank (Deutsche Bundesbank, 2017) in particular - have been at the forefront in championing the major one contribution of non-Neoclassical economists, the fact that banks create money when they create loans (Moore, 1979; Graziani, 1989; Chick \& Dow, 2002). They are also actively working on models which are outside the economic mainstream's obsession with micro-founded macroeconomics.

\section{Is History of Economic Thought Still Relevant in the 'Modeling' and 'Digital Eras'?}

The history of economic thought is absolutely essential, if only because so many good ideas have been lost by the profession, while bad ones have developed into the orthodoxy. There is much to be learnt from the greats that have been ignored by the mainstream, from Minsky (Minsky, 1982) and Godley (Godley \& Lavoie, 2007) in our current era right back to Richard Cantillon (Cantillon, 1755/2010) well before Smith. This particularly applies to the capacity to think dynamically, rather than in the equilibrium straitjacket that was imposed as a temporary means to make economics analytically tractable in the time of Jevons and Marshall, but which was ossified into gospel by their less gifted followers.

There are many great insights into the dynamics of actual capitalism that are in the literature but have been ignored by the mainstream. Richard Goodwin's brilliant trade cycle model, for example (Goodwin, 1967), was inspired by a fragment in Chapter 25 of Volume I of Marx's Capital (Marx, 1867/1965). Some mathematical economists believe that this model and extensions of it could form the basis of a new macroeconomics (Grasselli \& Costa Lima, 2012; Grasselli \& Maheshwari, 2017). Given how dead the prose is in mainstream textbooks, let alone the content, the classic works of economics can keep your soul alive even while your erstwhile teachers attempt to remove it.

It is important to read outside economics literature as well - particularly to learn the many modern techniques of analysis that economics has excluded from its lexicon via its obsession with equilibrium modelling. System dynamics (Radzicki, 1990; Radzicki \& Tauheed, 2009), chaos theory (Cvitanović, Artuso, Mainieri, Tanner, \& Vattay, 2019) and complexity theory are musts (Barnett, Chiarella, Keen, Marks, \& Schnabl, 2000)

\section{Are Ethics and Morals Relevant to the 'Economic Science'?}

Ethics are euthanized in Neoclassical economics from the moment the models of a utility maximizing individual and a profit maximizing firm are presented to students. Ethics have no room to develop when your starting perspective is that you should do whatever maximizes your utility, in isolation from the effects of your behavior on others. This perspective, which originated in Jeremy Benthams's philosophy of utilitarianism rather than Adam Smith, is more extreme in Neoclassical economics than it was with Bentham himself.

Once one acknowledges, as Neoclassical economics should after the Sonnenschein-Mantel-Debreu theorem, but does not, that a coherent model of a market cannot be generated from the model of an individual consumer, and therefore, that "demand and expenditure functions if they are to be set against reality must be defined at some reasonably high level of aggregation" (Kirman, 1989, p. 138), social classes and the effects of policy on them must be considered. 
It is highly likely that an economic policy that benefits one class will disadvantage others. The analysis can therefore no longer take a neutral stance, and just conclude - as cost-benefit analysis does - that the best policy is always the one with the highest net present value.

So yes, ethics and morality are essential to economics, but the mainstream's starting assumptions rule them out of bounds.

\section{What Implications Does the Reform Agenda Have for Islamic Economics?}

From my own limited exposure to Islamic economics, I feel that too much of its foundations were innocently but incorrectly constructed by trying to use the

\section{References}

Anderson, P. W. (1972). More Is Different. Science, 177(4047), 393-396.

Barnett, W. A., Chiarella, C., Keen, S., Marks, R., \& Schnabl, H. (Eds.). (2000). Commerce, complexity, and evolution: Topics in economics, finance, marketing, and management - Proceedings of the Twelfth International Symposium in Economic Theory and Econometrics. New York, USA: Cambridge University Press.

Blanchard, O. (2009). The State of Macro. Annual Review of Economics, 1, 209-228.

Blanchard, O. (2016, October 3). Further Thoughts on DSGE Models: What we agree on and what we do not [Blog post]. Retrieved from: https://bit.ly/2yltgJm

Blinder, A. S., Canetti, E. R. D., Lebow, D. E., \& Rudd, J. B. (1998). Asking about prices: a new approach to understanding price stickiness. New York, USA: Russell Sage Foundation.

Cantillon, R. (2010). An Essay on Economic Theory (C. Saucier, Trans., M. Thornton, Ed.). Alabama, USA: Ludwig von Mises Institute. (Original work published 1755)

Chick, V., \& Dow, S. (2002). Monetary Policy with Endogenous Money and Liquidity Preference: A Nondualistic Treatment. Journal of Post Keynesian Economics, 24(4), 587-607.

Cvitanović, P., Artuso, R., Mainieri, R., Tanner, G., \& Vattay, G. (2019). Chaos: Classical and Quantum (16th ed.). Retrieved from: https://bit.ly/2KnIVNV tools of mainstream economics to derive results consistent with Islamic philosophy. Islamic economics could benefit from abandoning this attempt completely, and forging itself on the foundations of modern complexity analysis. One insight this field gave me was that, contrary to my expectations, Islamic finance in terms of the borrower taking effectively an equity stake in a venture rather than a debt lien, was not sufficient to prevent economic crises from occurring (Keen, 2016). The issue seems to be the capacity for bankers' claims on the income streams of borrowers to grow, whatever form these claims take.

Insights like these could have practical implications for how Islamic finance should be implemented.

Deutsche Bundesbank. (2017). The role of banks, nonbanks and the central bank in the money creation process. Deutsche Bundesbank Monthly Report, 69(4), 13-33.

Ebeling, R. M. (2010). Political Economy, Public Policy and Monetary Economics: Ludwig Von Mises and the Austrian Tradition. Oxford, UK: Routledge.

Garrett, T. J. (2014). Long-run evolution of the global economy: 1. Physical basis. Earth's Future, 2(3), 127151.

Garrett, T. J. (2015). Long-run evolution of the global economy - Part 2: Hindcasts of innovation and growth. Earth System Dynamics, 6(2), 673-688.

Godley, W., \& Lavoie, M. (2007). Fiscal Policy in a Stock-Flow Consistent (SFC) Model. Journal of Post Keynesian Economics, 30(1), 79-100.

Goodwin, R. M. (1967). A growth cycle. In C. H. Feinstein (Ed.), Socialism, Capitalism and Economic Growth: Essays Presented to Maurice Dobb (pp. 5458). Cambridge, UK: Cambridge University Press.

Grasselli, M. R., \& Costa Lima, B. (2012). An analysis of the Keen model for credit expansion, asset price bubbles and financial fragility. Mathematics and Financial Economics, 6(3), 191-210.

Grasselli, M. R., \& Maheshwari, A. (2017). A comment on 'Testing Goodwin: growth cycles in ten OECD countries'. Cambridge Journal of Economics, 41(6), 1761-1766. 
Graziani, A. (1989). The Theory of the Monetary Circuit. Thames Papers in Political Economy, Spring, 1-26. Retrieved from: https://bit.ly/312TkVW

Keen, S. (1995). Finance and Economic Breakdown: Modeling Minsky's "Financial Instability Hypothesis". Journal of Post Keynesian Economics, 17(4), 607-635.

Keen, S. (2015). Post Keynesian Theories of Crisis. The American Journal of Economics and Sociology, 74(2), 298-324.

Keen, S. [ProfSteveKeen] (2016, October 16). Alternative economics 1: Credit, Islamic Finance, \& Preventing Economic Crises [Video File]. Retrieved from: https://youtu.be/c2NdGDGcj2Y?t=1822

Keen, S., Ayres, R. U., \& Standish, R. (2019). A Note on the Role of Energy in Production. Ecological Economics, 157, 40-46.

Kirman, A. (1989). The Intrinsic Limits of Modern Economic Theory: The Emperor Has No Clothes. The Economic Journal, 99(395), 126-139.

Krugman, P. (1996, November). What Economists Can Learn From Evolutionary Theorists. Retrieved from: http://web.mit.edu/krugman/www/evolute.html

Kuhn, T. (1970). The Structure of Scientific Revolutions. Chicago, USA: University of Chicago Press.

Lazear, E. P. (2000). Economic Imperialism. The Quarterly Journal of Economics, 115(1), 99-146.

Lee, F. S. (1999). Post Keynesian price theory. Cambridge, UK: Cambridge University Press.

Lorenz, E. N. (1963). Deterministic Nonperiodic Flow. Journal of the Atmospheric Sciences, 20(2), 130-141.
Marx, K. (1965). Capital: A Critique of Political Economy (S. Moore \& E. Aveling, Trans., F. Engels, Ed.). Moscow, Russia: Progress Press. (Original work published 1867)

McLeay, M., Radia, A., \& Thomas, R. (2014). Money creation in the modern economy. Bank of England Quarterly Bulletin, 54(1), 14-27.

Minsky, H. P. (1982). Can "it" happen again?: Essays on instability and finance. New York, USA: M.E. Sharpe.

Moore, B. J. (1979). The Endogenous Money Stock. Journal of Post Keynesian Economics, 2(1), 49-70.

Quesnay, F. (1759). Tableau Economique. Retrieved from https://bit.ly/2LL6XFF

Radzicki, M. J. (1990). Institutional Dynamics, Deterministic Chaos, and Self-Organizing Systems. Journal of Economic Issues, 24(1), 57-102.

Radzicki, M. J., \& Tauheed, L. (2009). In Defense of System Dynamics: A Response to Professor Hayden. Journal of Economic Issues, 43(4), 1043-1061.

Reardon, J. (2019). Dialogue on Reform in Mainstream Economics and its Implications for the Islamic Economics Discipline. Journal of King Abdulaziz University: Islamic Economics, 32(2), 61-75.

Sippel, R. (1997). An Experiment on the Pure Theory of Consumer's Behaviour. The Economic Journal, 107(444), 1431-1444.

Sonnenschein, H. (1972). Market Excess Demand Functions. Econometrica, 40(3), 549-563. 
Steve Keen is an Honorary Professor at the University College London and Distinguished Research Fellow at the Institute for Strategy, Resilience \& Security, London. He has retired from academic economics, largely in protest at the futility of trying to reform economics from within Universities and is now crowdfunded via https://www.patreon.com/ProfSteveKeen. Previously he was Professor of Economics at Kingston University, London, and University of Western Sydney, Australia. He was one of a handful of economists to anticipate the Global Financial Crisis of 2008, and won the Revere Award from the Real World Economics Review for being the economist who "gave public warning of the Global Financial Collapse and whose work is most likely to prevent another GFC in the future". He is the author of popular books Debunking Economics (2011) and Can We Avoid Another Financial Crisis? (2017), and over 70 refereed papers on diverse topics such as money creation, empirical analysis of credit dynamics, mathematical flaws in conventional economic theory. $\mathrm{He}$ designed the Open Source system dynamics program Minsky (https://sourceforge.net/ projects/minsky/), which extended the system dynamics paradigm by enabling financial flow equations to be derived from double entry bookkeeping tables. His current research interests include developing a software for monetary economic dynamics (see https://www.patreon.com/hpcoder), and integrating economics and ecological studies by properly acknowledging the role of energy in production.

E-mail: debunking@gmail.com 


\title{
الاقتصياد: ماذا نفعل لعلم غيرقابل للإصلاح؟
}

\author{
ستيف كين - n \\ أستاذ فخري، جامعة كلية لندن، \\ وزميل أبجاث المتميز، معهلد للإستراتيجية، والثبات والأمن (ISRS)، لندن
}

المستخلص: مَثَّلت الأزمة المالية لعام 2008م إخفاقاً كبيراً في النظرية الاقتصادية الكلاسيكية الحديثة

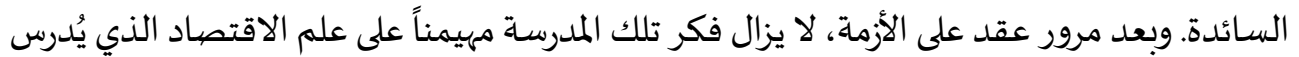

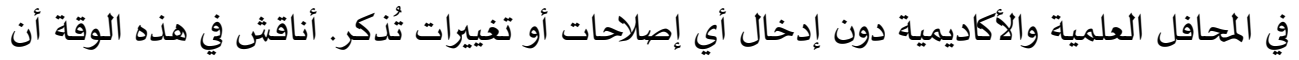

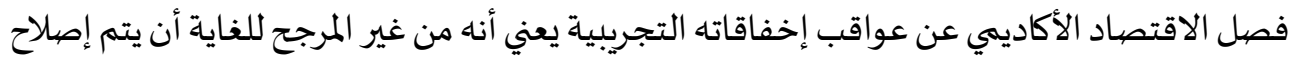

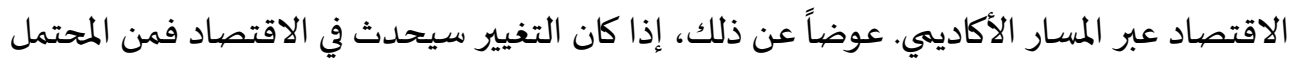

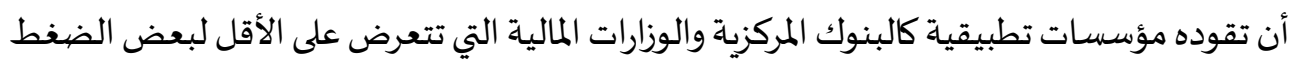
لإنتاج توقعات اقتصادية مفيدة. وبصرف النظر عن هذا، فإنني آمل في أن التخصصيات الناشئئة مثل

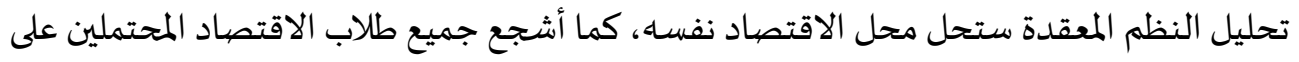

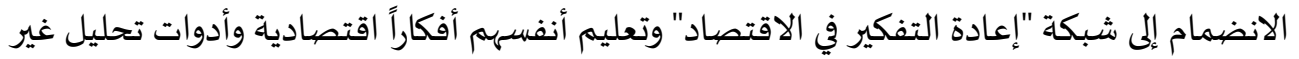
سائدة باستخدام موارد متاحة على شبكة المعلومات العالمية (الإنترنت). الكلمات الدَّالة: علم أصول التدريس، النماذج الإرشادية، التعليم، الاقتصاد الكلي، النظم المعقدة.

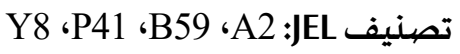

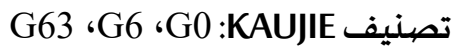

